\title{
SIMULASI DOCKING SENYAWA AKTIF DAUN BINAHONG SEBAGAI INHIBITOR ENZYME ALDOSE REDUCTASE
}

\section{DOCKING SIMULATION OF ACTIVE COMPOUNDS OF BINAHONG LEAVES AS INHIBITOR OF ENZYME ALDOSE REDUCTASE}

\author{
Andrio Suhadi $^{1 *}$, Rizarullah ${ }^{1}$, Feriyani $^{1}$ \\ ${ }^{1}$ Fakultas Kedokteran, Universitas Abulyatama, Aceh Besar \\ *email: andriosuhadi@gmail.com
}

\begin{abstract}
ABSTRAK
Sindroma metabolik merupakan masalah dunia yang disebabkan salah satunya oleh diabetes mellitus. Daun binahong merupakan tanaman yang sering digunakan untuk mengobati berbagai penyakit. Penelitian ini bertujuan untuk melihat aktivitas inhibisi senyawa daun binahong untuk menghambat aldose reductase yang berperan mengubah glukosa menjadi sorbitol dengan cara simulasi docking. Senyawa dari daun binahong adalah asam ursolat, vitexin dan oleonalat (ligan uji). Senyawa tersebut di ambil melalui situs pubchem, sedangkan enzyme aldose reductase (reseptor) didapat dari bank protein dunia dengan kode PDB 2HV5. Penelitian ini menggunakan teknik In Sillico dengan menggunakan perangkat lunak AutoDock Vina dan Discovery Studio serta Ligplot sebagai visualisasinya. Hasil optimasi gridbox dengan melakukan penambatan ulang ligan pembanding dan diperoleh RMSD sebesar $0,7 \AA$ A. Hasil docking menunjukkan energi bebas gibbs $(\Delta \mathrm{G})$ Aldose Reductase $(-11,7)$, Vitexin $(-8,3)$, Asam Ursolat $(-7,7)$ dan Oleonalat $(-8,6)$ yang menunjukan adanya reaksi inhibisi yang stabil dari senyawa daun binahong dan ligan pembanding. Berdasarkan aturan dari Lipinski's Rule menunjukan senyawa dari daun binahong memenuhi dari aturan Lipinski's Rule yang berarti dapat digunakan secara oral kecuali Vitexin dan ligan pembanding zopolrestat melebihi dari jumlah atom.
\end{abstract}

Kata Kunci : Daun Binahong, Molecular Docking, Zopolrestat. Oleonolat, Asam Ursolat

\begin{abstract}
The metabolic syndrome is the cause of death around the world caused by diabetic mellitus. Binahong leaf is a kind of plant that is widely used to treat various diseases. This study aims to investigate the inhibitory activity of binahong leaves compound in inhibiting the aldose reductase which has role of converting glucose into sorbitol by docking simulation. The compound of binahong leaves consists of ursolic acid, vitexin, and oleonolic acid (ligand testing). These compound were taken from Pub Chem site, while aldose reductase enzyme (receptor) was obtained from the world protein bank with PDB $2 H V 5$ code. This study incorporated in silica technique by using Auto dock vina software, Discovery Studio and Ligplot as visualization. The result of grid box optimization by redocking comparative ligand was $0.7 \AA$ RMSD. The docking result showed that the free Gibbs energy $(\Delta G)$ of aldose reductase was (-11.7), Vitexin (-8.3), Ursolic acid (-7.7) and Oleonolic acid (-8.6). These value suggested that there was a stable inhibition reaction from the binahong leaves compound and the comparative ligand. Based on the Lipinski Rule, the composition of binahong leaves compound meets the Lipinski Rule criteria which means this medicine can be used orally except for vitexin and comparative ligands of zopolrestate which exceed the number of the atom.
\end{abstract}

Keywords: binahong leaves, molecular docking, zopolrestat. oleonolic acid, ursolic acid 


\section{PENDAHULUAN}

Sindrom metabolik merupakan kumpulan dari beberapa gejala yang disebabkan ketidaknormalan metabolisme yang ada di dalam tubuh ditandai dengan resistensi insulin, obesitas, dislipidemia, hipertensi, dan gangguan toleransi glukosa. Cara yang paling sensitif, mudah dan murah untuk mendiagnosis sindrom metabolik adalah dengan pengukuran lingkar pinggang, tekanan darah dan profil lipid saat berpuasa. $^{1,2}$

Prevalensi terjadinya sindrom metabolik dari beberapa negara dan negara bagian didapatkan Turki tahun 2013 (15,6\%), Iran tahun 2010 (21,9\%), Asia Pasific 2017 (11,9\%), Amerika Selatan tahun 2011 (18,8\%), Asia Selatan tahun 2016 (26,1\%), Africa tahun 2012 (12,5\%), Malaysia tahun 2008 (34,3\%) dan Indonesia tahun $2006(28,4 \%)$ dari prevalensi yang didapatkan angka terjadinya sindrom metabolik cukup relatif tinggi dari beberapa Negara yang didapatkan. ${ }^{3,4}$

Diabetes mellitus merupakan penyakit dari gangguan metabolik yang ditandai dengan peningkatan kadar glukosa darah puasa lebih dari > $100 \mathrm{~g} / \mathrm{dL}$. Penyebab dari diabetes mellitus disebabkan kelainan kongenital, resistensi insulin dan pada saat hamil yang mengakibatkan tidak dapatnya glukosa diubah menjadi lemak untuk disimpan pada hati sebagai cadangan energi. ${ }^{5}$

Diabetes mellitus dapat menyebabkan komplikasi pada pembuluh darah dikarenakan teradinya aterosklerosis sehingga dapat menyebabkan terjadinya renopati, penyakit kardiovaskular, nefropati dan neuropati. Komplikasi diabetes mellitus merupakan komplikasi yang serius karena dapat menyebabkan kematian yang cepat dikarenakan hipoglikemia sehingga dapat menurunkan kesadaran dan menyebabkan kematian. ${ }^{6}$

Enzim aldose reductase merupakan salah satu enzim yang berperan penting pada jalur poliol yang menyebabkan komplikasi diabetes, peningkatan aktivitas aldose reductase akan menyebabkan akumulasi sorbitol. hal tersebut akan menyebabkan komplikasi diabetes antara lain: neuropati, retinopati, nefropati dan diabetes katarak, oleh karena itu diperlukan senyawa kimia yang dapat menghambat aktivitas enzim aldose reductase.

Indonesia kaya akan rempah-rempah dari ujung Sabang sampai ke Merauke. Indonesia dengan penduduk hampir mencapai 300 juta jiwa memiliki 30.000 spesies tumbuhan dan 940 di antaranya tumbuhan berkhasiat jenis. Tanaman binahong merupakan salah satu tanaman yang dimanfaatkan sebagai bahan obat tradiosional di Indonesia. Tanaman binahong (Anredera cordifolia (tenore) steenis) merupakan tanaman merambat, berbatang kecil, dan memiliki rizoma yang kuat serta memiliki daun yang relatif tidak besar. ${ }^{7}$

Flavonoid yang terkandung di daun binahong kering dan segar $11,23 \mathrm{mg} / \mathrm{kg}$ dan $7,81 \mathrm{mg} / \mathrm{kg}$. Vintexin dan asam ursolat merupakan jenis flavonoid yang diperoleh dari hasil identifikasi serbuk segar dan serbuk kering ekstrak etanol daun binahong yang memiliki fungsi medis dalam bidang kesehatan. Pada 
anredera cordifolia (tenore) steenis memiliki aktivitas sebagai antioksidan. ${ }^{8}$ Di Indonesia tanaman ini juga di gunakan untuk mengobati berbagai penyakit seperti menyembuhkan luka.

Tujuan penelitian ini bertujuan untuk melihat aktivitas inhibisi senyawa aktif daun binahong untuk menghambat aldose reductase yang berperan mengubah glukosa menjadi sorbitol dengan cara simulasi docking, dengan harapan dapat menjadi kandidat senyawa untuk mengahambat enzyme aldose reductase.

\section{METODE}

Penelitian ini menggunakan komputer dengan spesifikasi Intel ${ }^{\circledR}$ Inside CORE i3 CPU $2.00 \mathrm{GHz}, 6,00 \mathrm{~GB}$ of RAM dan system operasi Windows 8.1, AutoDock Tools, AutoDock Vina, LigPlot, Discovery Studio, Lipinski's Rule pada situs www.scfio.res/in, Protein Data Bank www.rscb.org/pdb dan ligan pada situs www.uniprot.com.

Sturktur 3D reseptor aldose reductase dengan PDB :2HV5 dan struktur pada daun binahong (asam ursolat, Vitexin dan Oleonolat) Prosedur penelitian. ${ }^{9}$

1. Penyiapan Struktur Protein

Struktur protein diunduh pada situs www.rscb.org/pdb, dipilih enzyme aldose reductase yang berasal dari human. Setelah didapatkan reseptor enzyme aldose reductase maka reseptor dibersihkan dari komponen lain dengan menggunakan software Discovery Studio.

2. Perancangan Struktur ligan

Perancangan struktur ligan dilakukan pada perangkat lunak Discovery Studio yang akan mengubah struktur 3D dalam format .ent menjadi .pdb

3. Preparasi file docking

Dengan menggunakan software AutoDock Tools, ligand dan reseptor diubah formatnya menjadi .pdbqt. merubah number of torsion pada ligan-ligan dan menentukan grid box pada reseptor

4. Molecular docking

Docking dilakukan dengan menggunakan software AutoDock Vina yang dijalankan dengan command prompt

5. Analisis dan visualisasi molecular docking Analisis docking dapat dilihat pada output dalam format notepad sedangkan visualisasi docking dapat dilihat menggunakan software LigPlot.

6. Lipinski's Rule

Untuk menilai kelayakan dapat dijadikan obat secara oral atau tidak dilakukan penelitian dengan menggunakan Lipinski's Rule pada situ www.scfio.res/in.

\section{HASIL}

Stuktur tiga dimensi enzyme aldose reductase diunduh melalui bank $\mathrm{PDB}$, yang di kritalisasi oleh Steuber H dengan kode 2HV5. Visualisasi untuk melihat Kristal menggunakan perangkat lunak Discovery Studio. Enzim aldose reduktase memiliki sisi aktif (active site) TRP 111, HIS 110, TYR 48, TRP 20, TRP 219, PHE 122, CYS 298, LEU 300, CYS 303 dan juga membawa ligand bawaan Zopolrestat dan NADPH . 


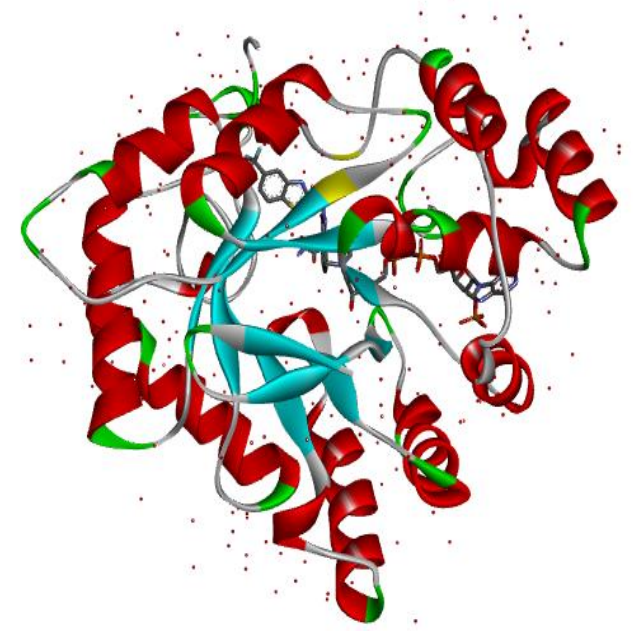

Gambar 1. Visualisasi 3D Reseptor Aldose Reductase

Aldose reduktase merupakan reseptor yang digunakan dalam penelitian. Enzim ini berasal dari manusia yang telah di kristalisasikan oleh Stuner H pada tahun 2006 dengan kode PDB 2HV5, terdapat juga kompleks yang diketahui merupakan inhibitor komersial untuk katarak. Aldose reductase 2HV5 dipilih menjadi reseptor karena memiliki ikatan protein yang lengkap dan dengan kerapatan $X$-Ray (RMSD) $1.66 \AA$.

Analisis kestabilan struktur reseptor digunakan Plot Ramachandran. Plot Ramachandran dibagi menjadi empat area. Area diluar garis pink adalah area yang dilarang (disallowed region), daerah di dalam garis biru adalah daerah favorit dan diijinkan (favourable and allowed region) (gambar 2). Data asam amino yang diperoleh pada daerah disukai (favourable) sebesar 98\%, daerah yang diizinkan (allowed) 99\% dan daerah dilarang (disallowed region) $1 \%$.

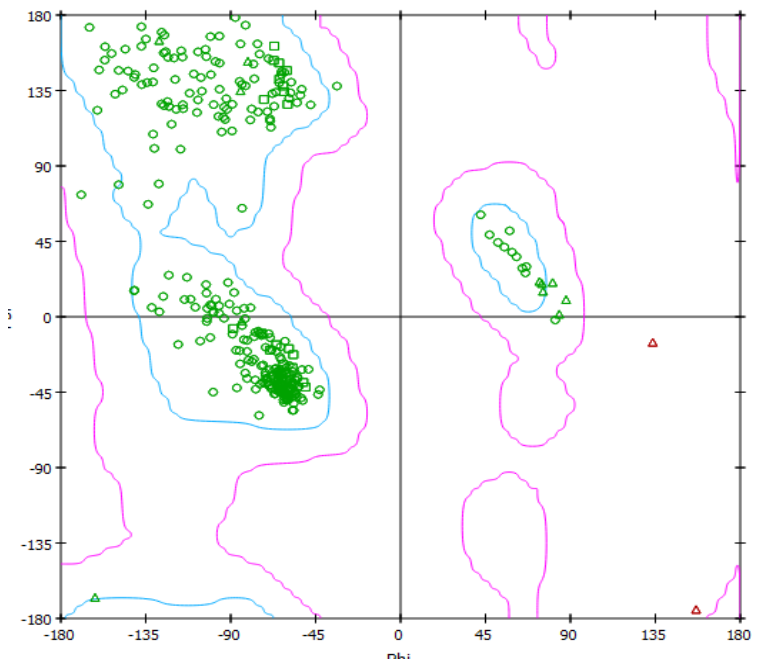

\section{Gambar 2. Plot Ramachandran Reseptor}

Struktur 3D pada resptor berkode 2HV5 telah ditentukan dengan metode kritalografi sinar-X ( $x$-ray crystallography) dan juga metode NMR (Nuclear Magnetic Resonance). Kombinasi dari kedua metode NMR dan X-Ray dapat mempresentasikan atau menggambarkan aktivitas, stabilitas dan fungsi yang mampu memberikan informasi struktural tingkat atom dari suatu protein pada keadaan unfolding yang penting dalam karakteristik proses pelipatan protein.

Hasil validasi metode penambatan ulang zopolrestat menunjukan nilai RMSD yang kecil yaitu $0.7 \AA$, selain itu zupolrestat berinterakasi dengan asam amnino sedikit berbeda dengan sebelum ligan tersebut ditambatkan ulang (redocking) yaitu TYR :309, CYS :80, TRP :79 LEU :300, TRP :111 CYS :298, LYS :77, TYR : 48, TRP :20, VAL :47, PHE :122, CYS :303 THR :113 PRO :310. Hasil penambatan memperlihatkan posisi ligan yang saling tumpang tindih. 


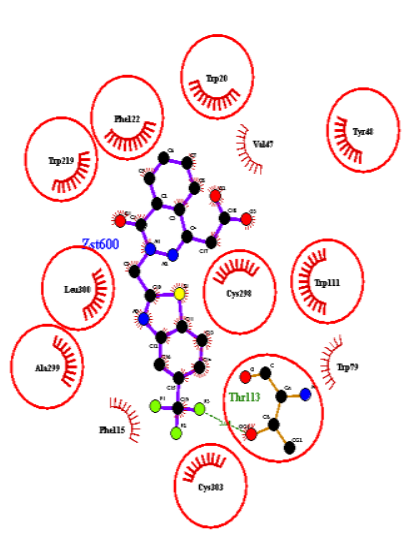

$\mathbf{a}$

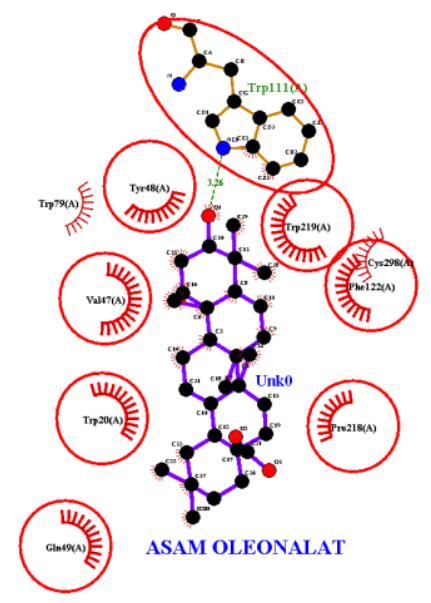

c

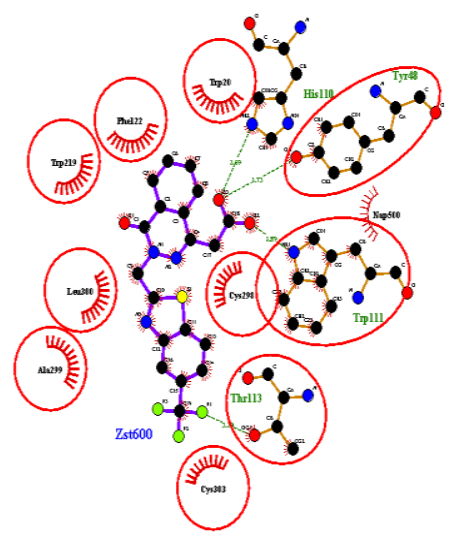

b

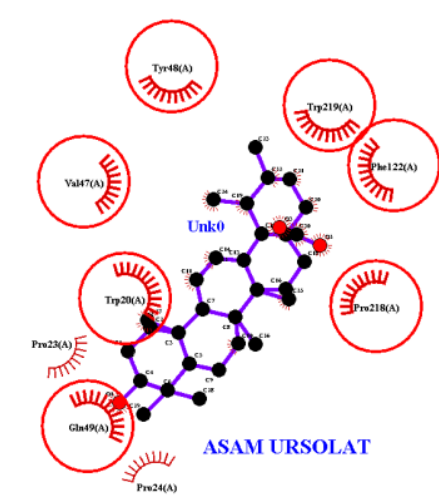

d

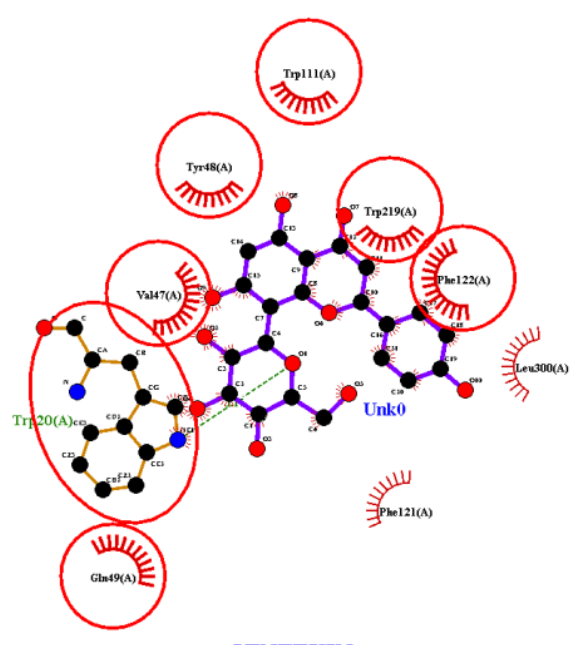

VINTEXIN

e

Gambar 3. a) interaksi asam amino dengan zopolrestat b) Hasil validasi interaksi asam amino dengan zopolrestat c) Hasil penambatan asam oleonalat d) Hasil penambatan asam ursolat e) Hasil penambatan vintexin 
lebih besar dari aturan dan jumlah donor hidrogen lebih dari 10.

Molekul obat yang tidak memenuhi aturan Lipinski tidak disarankan digunakan secara oral namun lebih disarankan untuk injeksi dan zopolrestat adalah obat komersil yang digunakan sebagai ligan pembanding adalah obat yang tidak digunakan secara oral.

Tabel 2. Aturan Lipinski's

\begin{tabular}{lllll}
\hline $\begin{array}{l}\text { Lipinski's } \\
\text { rule }\end{array}$ & $\begin{array}{l}\text { Zopol } \\
\text { restat }^{*}\end{array}$ & $\begin{array}{l}\text { Asam } \\
\text { Ursolat }\end{array}$ & $\begin{array}{l}\text { Vinte } \\
\text { xin }\end{array}$ & $\begin{array}{l}\text { Asam } \\
\text { oleon } \\
\text { olat }\end{array}$ \\
\hline A & 418 & 455 & 432 & 455 \\
B & 0 & 1 & 7 & 5,8 \\
C & 6 & 3 & 10 & 1 \\
D & 2,815 & 5,7 & $-0,065$ & 3 \\
E & 97 & 129 & 103 & 130 \\
\hline
\end{tabular}

Keterangan :

D* : Ligan Standart (obat komersial)

A : Massa atom relative $<500$

B $: \log \mathrm{P}<5$

C : Donor ikatan $\mathrm{H}<5$

D : Akseptor ikatan $<10$

E : Molar refraktifiti $40-130$

\section{PEMBAHASAN}

Aldose reduktase merupakan reseptor yang digunakan dalam penelitian. Enzim ini berasal dari manusia yang telah di kristalisasikan oleh Steuber H pada tahun 2006 dengan kode PDB 2HV5, terdapat juga kompleks yang diketahui merupakan inhibitor komersial untuk katarak. Aldose reduktase (2HV5) dipilih menjadi reseptor karena memiliki ikatan protein yang lengkap dan dengan kerapatan $X$-Ray (RMSD) $1.66 \AA{ }^{10}$

Analisis pemilihan reseptor yang baik digunakan ditinjau dari ketepatan pada pembentukan sudut-sudut dihedral untuk membentuk suatu konformasi. Sudut dihedral dari masing-masing residu dapat menentukan konformasi residu pada protein dengan melihat dari diagram pada sudut dihedralnya, diagram ini disebut dengan Plot Ramachandran (Gambar 2). Visualisasi koordinat internal dilakukan dengan Plot Ramachandran untuk mengetahui kualitas struktur tiga dimensi protein hasil dari kristalisasi. $^{11}$

Residu yang membentuk kluster dapat menunjukan bentuk struktur sekunder protein. Sudut phi $(\phi)$ dan psi $(\psi)$ dimiliki setiap asam amino penyusun protein, sehingga setiap residu asam amino dapat digambarkan sebagai satu koordinat (plot). Plot-plot yang menggambarkan residu asam amino pada struktur protein ini yang disebut Plot Ramachandran. ${ }^{11}$

Plot residu non-glisin dapat menentukan kualitas struktur protein dengan melihat adanya plot residu non-glisin yang terletak pada wilayah sudut dihedral yang dilarang (disallowed region) dan yang paling disukai (favourable region), bila residu non-glisin pada daerah terlarang lebih dari $15 \%$ dan residu pada daerah yang paling disukai kurang dari $80 \%$ maka struktur protein tersebut memiliki kualitas struktur yang kurang baik. ${ }^{12}$ Hasil analisis struktur (Gambar 2) menunjukan bahwa protein reseptor Aldose Reductase (2HV5) memiliki residu glisin pada daerah terlarang kurang dari $1 \%$ dan memiliki residu pada daerah paling disukai lebih dari 99\%, sehingga kedua protein memiliki kualitas yang sangat baik. 
Berdasarkan hasil penambatan ke empat senyawa tersebut diperoleh energi bebas gibbs. Energi bebas gibbs $(\Delta \mathrm{G})$ merupakan salah satu parameter kestabilan konformasi antara ligand dan reseptor. Reaksi-reaksi metabolisme dalam tubuh ditinjau dari termodinamika berlangsung secara eksergonik dan endergonik. Reaksi eksergonik adalah reaksi yang menghasilkan energi bebas gibbs, yaitu energi yang digunakan untuk melakukan kerja pada temperatur dan tekanan yang tetap. ${ }^{13}$

Reaksi eksergonik menyebabkan energi bebas molekul peraksi menjadi turun, karena energi bebasnya dibebaskan pada saat bereaksi, oleh karena itu energi bebas produk menjadi lebih rendah dibandingkan energi bebas pereaksi, semakin rendah energi bebas suatu molekul, maka molekul tersebut semakin stabil dan reaksi berjalan secara spontan, hal ini disebut dengan kesetimbangan termodinamika, semakin negatif energi bebas maka reaksi akan semakin spontan atau akan cepat membentuk konformasi yang stabil.

Semakin rendah atau terjadi kenaikan nilai negatif dari harga $\Delta \mathrm{G}$, maka ikatan kompleks enzim-ligan akan semakin kuat karena kestabilan dan kekuatan interaksi nonkovalen pada kompleks enzim-ligan dapat dilihat dari besarnya energi bebas yang dilepaskan saat interaksi pada kompleks enzimligan terbentuk. ${ }^{14}$ Analisis energi ikatan bebas $(\Delta \mathrm{G})$ hasil penambatan molekular untuk senyawa asam ursolat, vintexin, dan asam oleonolat (gambar 4) menghasilkan nilai $-7,7$, $-8,3$ dan $-8,6 \mathrm{kkal} / \mathrm{mol}$ sedangkan zopolrestat memiliki nilai $\Delta \mathrm{G}$ yang relatif rendah dengan nilai $-11,2 \mathrm{kkal} / \mathrm{mol}$ (Gambar 4). Zopolrestat adalah ligan pembanding yang merupakan obat komersial katarak karena kemampuanya sebagai inhibitor enzim aldose reductase. Dari data nilai $\Delta \mathrm{G}$ dapat disimpulkan bahwa dari 4 senyawa tersebut memiliki aktivitas terhadap enzyme aldose reductase. Hal tersebut telah dibuktikan dengan penelitian yang dilakukan oleh Lee et al yang menyatakan bahwa asam ursolat dan turunanya memiliki aktivitas inhibisi terhadap enzyme aldose reductase. ${ }^{15}$

Berdasarkan tabel penambatan senyawa binahong tersebut sesuai penelitian Dacal (2016) yang menyatakan bahwa active site dari aldose reductase yaitu TYR 48, TRP 20, TRP 219, TRP 111, TRP $20 .{ }^{16}$

Kriteria obat yang baik harus mengikuti sebuah aturan Lipinski's Rule yang dikembangkan oleh Christopher A. Obat yang diberikan pada pasien akan melintasi tubuh berdasarkan berbagai faktor yang dapat menghilangkan merusak atau mencegahnya mencapai sisi target yang diinginkan. Empat faktor tersbut yaitu absorbs, distribusi, metabolisme dan ekskresi, dalam farmakologi disebut farmako kinetik atau kemampuan yang dilakukan tubuh terhadap obat. ${ }^{17}$

Mempertimbangkan aspek farmako kinetik sangat penting selama merancang suatu obat karena tidak mungkin bisa berinteraksi dengan target bila tidak bisa mencapai target sehingga ditemukanlah aturan, lima aturan Lipinski atau yang disebut dengan the rule of five atau Lipinski's Rule. Obat yang mampu 
mencapai target bila diberikan oral harus memenuhi syarat berikut: berat molekul kurang dari 500, jumlah gugus donor ikatan hydrogen tidak lebih dari 5, jumlah gugus penerima ikatan tidak lebih dari 10 , nilai $\log \mathrm{P}$ kurang dari +5 dan pefraktifiti molar 40-130. ${ }^{18}$

Obat yang tidak memenuhi salah satu aturan Lipinski, maka obat tersebut tidak dapat digunakan secara efektif dengan oral dan disarankan melalui injeksi karena akan berbahaya di dalam tubuh, filter Lipinski dilakukan dengan menggunakan tools online situs http://www.scfbio-iitd.res.in/software/ drugdesign/Lipinski.jsp. ${ }^{19}$

Berdasarkan hasil filter aturan Lipinski (Tabel.1), senyawa metabolik sekunder dari daun binahong memenuhi the rule of five sehingga penggunaan secara oral dapat dilakukan kecuali vitexin. Zopolrestat tidak memenuhi aturan Lipinski jumlah gugus donor ikatan hidrogen lebih 5. Nilai $\mathrm{Mr}$ (berat molekul), H-donor dan $\mathrm{H}$-acceptor merupakan besaran permeabilitas suatu obat untuk dapat melewati lapisan lipid bilayer dari sel, nilai log $\mathrm{P}$ berhubungan dengan hidrofobisitas molekul obat, semakin besar nilai log P maka semakin hidrofobik molekul tersebut. ${ }^{9}$

Salah satu syarat suatu senyawa dapat digunakan sebagai molekul obat yaitu tidak boleh terlalu hidofobik yang akan mempengaruhi daya tahan lebih lama di lapisan lipid bilayer. Senyawa obat akan tertahan terlalu lama dan terdistribusi secara luas di dalam tubuh sehingga menyebabkan selektifitas ikatan terhadap protein target menjadi berkurang. Nilai log $\mathrm{P}$ yang terlalu negatif juga tidak disarankan karena jika obat terlalu hidrofilik maka obat tidak mampu melawati lapisan lipid bilayer. ${ }^{20}$

\section{KESIMPULAN}

Asam amino yang berperan dalam sisi aktif adalah TRP 111, HIS 110, TYR 48, TRP 20, TRP 219, PHE 122, CYS 298, LEU 300 dan CYS 303. Berdasarkan pengujian dengan Lipinski's Rule senyawa pada daun binahong dapat digunakan sebagai obat oral kecuali senyawa vitexin dan senyawa pembanding zopolrestat tidak memenuhi aturan Lipinski's Rule. Energi bebas gibbs $(\Delta \mathrm{G})$ yang terdapat pada senyawa daun binahong asam ursolat $-7,7$ dan vitexin $8,3 \mathrm{kkal} / \mathrm{mol}$ dan zopolrestat lebih $63 \mathrm{kkal} / \mathrm{mol}$. Sehingga berpontesi sebagai inhibitor dari aldose reductase. Senyawa pada daun binahong dapat digunakan sebagai inhibitor aldose reductase dan dapat digunakan secara oral karena sudah memenuhi dari kriteria dari Lipinski's Rule kecuali Vitexin dan energi gibssnya juga lebih positif dari zopolrestat sehingga tidak terlalu lama berada di dalam tubuh.

\section{SARAN}

Berdasarkan studi penelitian penambatan molekul senyawa katif daun binahong mampu menginhibisi enzim aldose reduktase, untuk itu perlu dilakukan penelitian lebih lanjut secara in vivo. Namun, untuk lebih mendukung hasil penelitian perlu penelitian secara molekular dinamic guna mengetahui tingkat efektifitas suhu dan $\mathrm{pH}$ pada orang normal. 


\section{UCAPAN TERIMAKASIH}

Ucapan terimakasih kami ucapkan setinggi-tingginya kepada Dekan Fakultas Kedokteran Universitas Abulyatama dan jajaranya, dan kami ucapkan terimkasih juga kepada dr.Maryan Suhadi, M.Kes yang telah mendukung pelaksanaan penelitian ini dari berbagai aspek, semoga dengan terbitnya jurnal ini dapat membantu mengembangkan ilmu pengetahuan pada semua orang.

\section{DAFTAR PUSTAKA}

1. Al-Nakeeb Y, Lyons $\mathrm{M}$, Collins $\mathrm{P}, \mathrm{Al}-$ Nuaim A, et al. Obesity, Physical Activity and Sedentary Behavior Amongst Britisht and Saudi Youth: a cross-cultural study. Int $J$ Environ Reseacrh Public Heal. 2012;9(4).

2. Rizzo A, Goldberg T, Silva C, Kurokawa C, Nunes H. Metabolic Syndrome Risk Factors In Overweight, Obese, and Extremely Obese Brazilian Adolescents. Nutr J. 2013;12(19).

3. Ranasinghe $\mathrm{P}$, Mathangasinghe $\mathrm{Y}$, Jayawardena R, Hills AP, Misra A. Prevalence and trends of metabolic syndrome among adults in the asia-pacific region: a systematic review. BMC Public Health. 2017;17(101):1-9. doi:10.1186/s 12889-017-4041-1.

4. Ansarimoghaddam A, Ali H, Iraj Z, Sohrab I, Ali H. Diabetes \& Metabolic Syndrome : Clinical Research \& Reviews Prevalence of metabolic syndrome in Middle-East countries : Meta-analysis of cross-sectional studies. Diabetes Metab Syndr Clin Res Rev. 2017. doi:10.1016/j.dsx.2017.11.004.

5. Diabetes DOF. Diagnosis and Classification of Diabetes Mellitus. Am Diabetes Assoc. 2013;36:67-74. doi:10.2337/dc13-S067.

6. Chawla A, Chawla R, Jaggi S. Microvascular and Macrovascular Complications In Diabetes Mellitus: Distinct or Continuum. Indian J Endocr Metab. 2016;20(4). doi:10.4103/22308210.183480 .
7. KEMENKES RI. Situasi Gangguan Penglihatan Dan Kebutaan. Jakarta; 2013.

8. Selawa W, Runtuwene MRJ, Citraningtyas G. Kandungan flavonoid dan kapasitas antioksidan total ekstrak etanol daun binahong

[Anredera cordifolia(Ten.)Steenis.]. Pharmacon J Ilm Farm - UNSRAT. 2013;2(1):18-23.

9. Setiawan T, Ambarsari L, Sumaryada T. Anticancer Study of Wonogiri's Curcuma Xanthorhiza roxb Ethanol Fraction As Jamu by Flexible Methods. Int J Hybrid Inf Technol. $2017 ; 10(1)$. doi:10.14257/ijhit.2017.10.1.24.

10. Steuber H, Zentgraf M, Gerlach C, et al. Expect the Unexpected or Caveat for Drug Designers : Multiple Structure Determinations Using Aldose Reductase Crystals Treated under Varying Soaking and Co-crystallisation Conditions. $\mathrm{J} \mathrm{Mol}$ Biol. 2006;363(1):174-187. doi:10.1016/j.jmb.2006.08.011.

11. Baxevanis. Bioinformatics a Practical Guide to The Analysis of Genes and Proteins Second Edition. 2nd ed. WileyInterscience; 2001.

12. Bosco K, Brasseur R. The Ramachandran Plots of Glycine and Pre-Proline. BMC STRUCT BIOl. 2005;5(14). doi:10.1186/1472-6807-5-14.

13. Mardianingrum R, Herlina T, Supratman U. Isolasi dan Molecular Docking Senyawa 6,7- Dihidro-17 Hidroksierisotrin Dari Daun Dadap Belendung (Erythrina Poeppigian) Terhadap Aktivitas Sitotoksik Antikanker Payudara MCF-7. Chim er Nat Acta. 2013;3(3). doi:10.24198/cna.v3.n3.9213.

14. Kartasasmita RE, Herowati R, Harmastuti $\mathrm{N}$, Gusdinar T. Querectin Derivatives Docking Based On Study of Flavonoids Interaction to Cyclooxygenase -2 Docking Turunan Kuersetin Berdasarkan Studi Interaksi Flavonoid Terhadap Enzim. IndoJ.chem. 2010;9(2):297-302.

15. Lee EH, Popov SA, Lee JY, et al. Inhibitiory Effect of Ursolic Acid Dericaties o Recombinant Human Aldose Reductase. Russ J Bioorganic Chem. 2011;37(69). doi:10.1134/S1068162011050050.

16. Díez-Dacal, Sánchez-Gómez, Sánchez- 
Murcia, et al. Molecular Interactions and Implication of Aldose Reductase Inhibition by PGA1 and clinically used prostaglandins. Mol Phamacol. 2016;89(1):42-52. doi:10.1124/mol.115.100693.

17. FKUI DF. Farmakologi Dan Terapi. 6th ed. Jakarta; 2013.

18. Rachmania RA, Supandi, Larasati OA. Analisis In-Silico Senyawa Diterpenoid Lakton Herba Sambiloto (Andrographis Paniculata Ness) Pada Reseptor Alpha-
Glucosidase Sebagai Anti Diabetes Tipe II. Pharm J Indones. 2015;12(2).

19. A.Lipinski C. Lead and Drug Like Compounds : The Rule Of Five Revolution. Drug Discov. 2004;1(4). doi:0.1016/j.ddtec.2004.11.007.

20. Choy Y Bin, Prausnitz MR. The Rule of Five for Non-Oral Routes of Drug Delivery: Ophthalmic, Inhalation and Transdermal. 2011. doi:10.1007/s11095010-0292-6. 